\title{
Pertumbuhan dan Produksi Daun Torbangun (Plectranthus amboinicus Spreng.) dengan Pemupukan Organik dan Pemangkasan
}

\author{
Growth and Shoot Production of Torbangun (Plectranthus amboinicus Spreng.) \\ with Organic Fertilizer and Pruning
}

\section{Nafi’atul Munawaroh, Sandra Arifin Aziz*}

${ }^{1}$ Departemen Agronomi dan Hortikultura, Fakultas Pertanian, Institut Pertanian Bogor (Bogor Agricultural University), J1. Meranti, Kampus IPB Darmaga, Bogor 16680, Indonesia Telp.\&Fax. 62-251-8629353 e-mail agronipb@indo.net.id

*Penulis untuk korespondensi: sandraaziz@yahoo.com

Disetujui 24 Desember 2013/ Published Online 10 Januari 2014

\begin{abstract}
Torbangun is a nutritious crop that increasebreast milk because its lactagogen content. Most study of torbangun plants focuses on pharmacological characteristics of plant. There is a need for research in cultivation techniques using organic fertilizer and pruning. The purpose of this study was to investigate the effect of organic fertilizer and pruning on the growth and leaf production of torbangun plant. This study used randomized block design (RBD) in the first experiment with fertilizer factor and split plot design in the second experiment with fertilizer and pruning. Both of the experiment used Tukey's (Honestly Significant Difference) test. Organic fertilizationis divided into five levels: without fertilizer, cowmanure+rock phosphate, cowmanure+rice-hullash, rock phosphate+rice-hullash, and cowmanure+rock phosphate+ricehullash. Pruningis consisted of 2 levels: without pruning and with pruning. The results showed that fertilization using cowmanure+rock phosphate+rice-hullash increased shoot fresh weight of 125.21\% compared to without fertilization. Pruning reduced plant biomass and leaf number. Torbangun growth is slow, so harvesting should have been done in a longer interval.
\end{abstract}

Keywords: cowmanure, phosphate, rice-hullash

\section{ABSTRAK}

Tanaman torbangun berkhasiat untuk memperlancar air susu ibu (ASI) karena mengandung laktagogen. Penelitian mengenai tanaman torbangun lebih banyak di bidang farmakologinya saja, oleh sebab itu perlu adanya penelitian di bidang teknik budi daya dengan menggunakan pupuk organik dan pemangkasan. Tujuan penelitian ini adalah untuk mendapatkan pengaruh pupuk organik dan pemangkasan terhadap pertumbuhan dan produksi daun torbangun. Rancangan penelitian ini menggunakan rancangan acak kelompok (RAK) pada siklus 1 dengan faktor pemupukan, dan rancangan perlakuan Split plot pada siklus 2 dengan pemupukan sebagai petak utama dan pemangkasan sebagai anak petak. Rataan hasil pada masing-masing siklus diuji lanjut menggunakan uji beda nyata jujur (BNJ). Pemupukan organik terbagi menjadi 5 taraf; tanpa pemupukan, pupuk kandang sapi+fosfat alam, pupuk kandang sapi+abu sekam padi, fosfat alam+abu sekam padi, dan pupuk kandang sapi+fosfat alam+abu sekam padi. Pemangkasan terbagi menjadi 2 taraf; tanpa dipangkas dan dipangkas. Hasil penelitian ini menunjukkan bahwa pemupukan yang menggunakan pupuk kandang sapi+fosfat alam+abu sekam padi dapat meningkatkan bobot basah pucuk $125.21 \%$ dibandingkan dengan perlakuan tanpa pemupukan. Pemangkasan menurunkan biomasa tanaman dan jumlah daun. Pertumbuhan tanaman torbangun termasuk lambat, sehingga pemanenan harus dilakukan pada umur tanaman yang lebih lama.

Kata kunci : abu sekam padi, fosfat alam, pupuk kandang sapi

\section{PENDAHULUAN}

Tanaman torbangun merupakan tanaman sayuran yang umum dikonsumsi para ibu setelah melahirkan di Sumatera Utara. Tanaman ini bersifat laktagogen (memperlancar air susu ibu (ASI)), dapat menyembuhkan sariawan, influenza, 
rheumatik, dan sakit kepala (Siagian dan Rahayu, 2000), mengandung kadar mineral yang cukup tinggi, salah satunya zat besi sehingga sayur ini sangat baik dikonsumsi untuk meningkatkan produksi ASI (Damayanthi et al., 2005). Damanik (2005) melaporkan bahwa sop daun torbangun mampu meningkatkan status gizi mikro ibu menyusui. Orang Sumatera mendapatkan tanaman torbangun bukan melalui tanaman budi daya, namun dari pengambilan langsung di hutan. Tanaman torbangun tumbuh baik di hutan tanpa adanya hara yang ditambahkan kedalam tanah, oleh sebab itu penelitian ini mencoba melihat produksi daun torbangun lebih baik atau tidak jika diberikan unsur hara ke dalam tanah.

Saat ini penelitian lebih banyak di bidang farmakologinya saja, oleh karena itu perlu adanya penelitian di bidang teknik budi daya. Teknik budi daya dengan menentukan jenis pupuk organik yang tepat dan pemangkasan yang tepat diharapkan mampu menghasilkan produksi yang lebih baik dibandingkan dengan pembibitan yang selama ini dilakukan.

Pemupukan organik saat ini sangat dianjurkan karena manfaatnya lebih baik dibandingkan pemupukan anorganik. Beberapa keuntungan diantaranya dapat mempengaruhi sifat fisik, kimia, biologi dalam tanah (Sutanto, 2002). Penelitian ini menggunakan pupuk kandang sapi (PKS) sebagai pengganti pupuk nitrogen $(\mathrm{N})$ karena bahan organik berupa pupuk kandang sapi matang dapat memperbaiki pertumbuhan dan produksi buah tomat (Pujisiswanto dan Pangaribuan, 2008), pupuk fosfat alam (FA) sebagai pengganti pupuk fosfor (P) karena pemberian fosfat alam dengan dosis 30,60 , dan $90 \mathrm{~kg} \mathrm{P} \mathrm{ha}{ }^{-1}$ berturut-turut meningkatkan $\mathrm{P}$ tersedia tanah 247,356 , dan 592\% dibandingkan tanpa fosfat alam (Noor, 2003), dan pupuk abu sekam padi (ASP) sebagai pengganti pupuk kalium (K) karena abu sekam padi dengan dosis 2 ton ha ${ }^{-1}$ mempunyai pengaruh yang sama dengan $\mathrm{KCl}$ dengan dosis $150 \mathrm{~kg} \mathrm{ha}^{-1}$ (Sudaryono, 2002).

Tindakan agronomis untuk memperbaiki teknik budi daya selain pemupukan adalah pemangkasan. Pemangkasan bertujuan untuk merangsang terbentuknya tunas vegetatif, sehingga bidang percabangan lebih luas dan memungkinkan untuk meningkatkan produksi tanaman. Menurut Hartmann dan Kester (1983) pemangkasan menyebabkan adanya rejuvenasi jaringan dewasa. Rejuvenasi ini secara fisiologis menambah vigor dari bahan setek.

Penelitian ini bertujuan untuk mendapatkan pengaruh pupuk organik dan pemangkasan terhadap pertumbuhan dan produksi daun torbangun serta mendapatkan jenis pupuk organik yang tepat untuk pertumbuhan dan produksi daun torbangun. Hipotesisnya adalah terdapat takaran pupuk organik dan pemangkasan yang menghasilkan pertumbuhan dan produksi daun tanaman torbangun yang maksimal.

\section{BAHAN DAN METODE}

Penelitian ini dilaksanakan pada bulan November 2012 sampai bulan April 2013. Pembibitan dilaksanakan satu bulan di kebun biofarmaka, Cikabayan IPB. Penanaman dilaksanakan di kebun percobaan Leuwikopo, Darmaga, Kabupaten Bogor dengan ketinggian tempat $\pm 250 \mathrm{~m}$ di atas permukaan laut. Analisis tanah dilakukan di laboratorium Ilmu Tanah dan Sumberdaya Lahan, Departemen ITSL, Fakultas Pertanian IPB.

Bahan-bahan yang digunakan pada penelitian ini adalah: bibit tanaman torbangun berumur 1 bulan, lahan seluas $375 \mathrm{~m}^{2}$, pupuk kandang kotoran sapi, fosfat alam, abu sekam padi. Alat yang digunakan antara lain: alat budidaya pertanian secara umum, meteran, ajir, timbangan elektronik, gunting, kertas, plastik, oven dan alat tulis.

Penelitian ini dilaksanakan secara paralel terhadap dua siklus pertumbuhan tanaman torbangun. Siklus pertama menggunakan rancangan acak kelompok (RAK) dengan satu faktor, yaitu pemupukan dengan 5 taraf dosis pupuk organik (Tabel 1). Setiap perlakuan diulang tiga kali, sehingga terdapat 15 satuan percobaan. Dosis pupuk kandang sapi dan abu sekam yang digunakan pada penelitian ini mengacu pada dosis yang digunakan pada penelitian Farchany (2012), sedangkan dosis pupuk fosfat alam yang digunakan mengacu pada hasil uji laboratorium Departemen ITSL (2012). Penelitian pada siklus kedua menggunakan rancangan lingkungan rancangan acak kelompok (RAK) dengan dua faktor dan rancangan perlakuan rancangan Splitplot dengan pemupukan sebagai petak utama dan pemangkasan sebagai anak petak. 
Tabel 1. Kombinasi perlakuan pupuk organik

\begin{tabular}{lccc}
\hline \multirow{2}{*}{ Perlakuan } & \multicolumn{3}{c}{${\text { Dosis }\left(\text { ton } \text { ha }^{-1}\right)}$} \\
\cline { 2 - 4 } & Pupuk kandang sapi (PKS) & ${\text { Fosfat alam }(\text { FA })^{2}}$ & Abu sekam padi(ASP) \\
\hline PKS + FA & 12.3 & 1.5 & 0 \\
PKS + ASP & 12.3 & 0 & 5.5 \\
FA + ASP & 0 & 1.5 & 5.5 \\
PKS+FA+ASP & 12.3 & 1.5 & 5.5 \\
Kontrol & 0 & 0 & 0 \\
\hline
\end{tabular}

${ }^{1}$ kandungan N 1.29\% (Farchanny 2012)

${ }^{3}$ kandungan $\mathrm{K}_{2} 01.10 \%$ (Farchanny 2012)

${ }^{2}$ kandungan $\mathrm{P}_{2} \mathrm{O}_{5} 2.87 \%$ (Laboratorium Dept. ITSL 2012)

Aplikasi pemupukan dilakukan 2 kali, 2 minggu sebelum penanaman di lapang (umur tanaman 4 minggu) dan sebelum pemangkasan yaitu 14 minggu setelah tanam (MST). Pemangkasan dilakukan setelah pemupukan kedua, yaitu 15 MST. Panen dilakukan 3 kali, yaitu umur 8, 12, dan 17 MST. Kriteria layak panen tanaman torbangun adalah memiliki 3 pasang daun yang terbuka sempurna dan menyisakan 2 pasang daun dibawahnya.

Parameter yang diamati pada dua siklus tersebut dibedakan menjadi pertumbuhan tanpa panen dan pertumbuhan dengan panen. Parameter pertumbuhan tanpa panen diamati dua minggu sekali. Peubah pengamatannya antara lain luas daun, indeks luas daun, bobot basah tanaman, bobot kering tanaman, luas daun spesifik, laju asimilasi bersih dan laju tumbuh relatif. Parameter pertumbuhan dengan panen diamati seminggu sekali. Peubah pengamatannya antara lain tinggi tanaman, lebar tajuk tanaman, jumlah cabang, jumlah pucuk yang dipanen dan bobot basah pucuk yang dipanen. Parameter jumlah pucuk dan bobot basah pucuk diamati ketika panen.

Data pengamatan yang diperoleh dianalisis menggunakan uji $\mathrm{F}$ pada taraf $1 \%$, data yang berpengaruh nyata dilanjutkan dengan uji beda nyata jujur (BNJ) pada taraf $5 \%$.

\section{HASIL DAN PEMBAHASAN}

Penelitian dilaksanakan di kebun percobaan Leuwikopo, Darmaga. Berdasarkan hasil analisis tanah yang dilakukan sebelum aplikasi perlakuan didapatkan bahwa $\mathrm{pH}$ tanah termasuk masam dengan nilai 4.9.Kadar C-organik dan N-total tergolong sedang dengan nilai berturut-turut 2.39 dan $0.24 \%$. Kandungan P dan $\mathrm{K}$ tergolong sangat

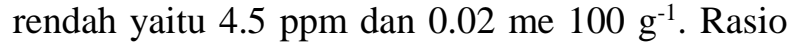
$\mathrm{C} / \mathrm{N}$ tergolong rendah, yaitu $9.96 \%$ (Laboratorium ITSL 2012 dan Staf Pusat Penelitian Tanah (1983) dalam Hardjowigeno (2007)). Pada awal penelitian dilakukan perlakuan dasar yang bertujuan menetralkan lahan. Komposisi perlakuan dasar tersebut antara lain arang sekam dan kapur tanah dengan dosis masing-masing 2 ton ha ${ }^{-1}$.

Penelitian berlangsung dari bulan Desember 2012 sampai bulan April 2013 dengan kondisi curah hujan rata-rata adalah $353.4 \mathrm{~mm} \mathrm{bulan}^{-1}$ sedangkan suhu rata-ratanya sebesar $26{ }^{\circ} \mathrm{C}$ dan intensitas penyinaran matahari sebesar 273.4 cal $\left(\mathrm{cm}^{-2}\right)$ (BMKG Darmaga 2013). Penyulaman dilakukan sampai minggu ke dua setelah penanaman. Lahan ini ternaungi oleh pohon kopi dengan persentase rata-rata naungannya $\pm 35 \%$.

Pengamatan hama dan penyakit serta pengendalian gulma dilakukan secara manual. Hama yang sering muncul pada tanaman ini adalah ulat jengkal. Penyakit yang terdapat pada tanaman torbangun yang berumur 6 minggu setelah tanam adalah busuk batang. Salah satu cara untuk mengendalikannya adalah dengan mencabut tanaman yang terkena serangan kemudian menggantinya dengan bibit yang sehat. Gulma yang sering muncul di sekitar tanaman torbangun adalah gulma golongan daun lebar, antara lain Borreria alata, Caladium bicolor, Setaria plicata, dan Mimosa pudica.

\section{Siklus 1}

\section{Pertumbuhan Tanpa Panen}

Pengamatan pertumbuhan tanpa panen siklus 1 dimulai pada umur 6 sampai 12 MST.Pemupukan berpengaruh sangat nyata terhadap laju asimilasi bersih dan laju tumbuh relatif pada 6-8 MST.

Tabel 2 menunjukkan bahwa luas daun dan indeks luas daun pada awal pengamatan (umur 6 MST) nilai tertinggi terdapat pada perlakuan PKS+FA, dan pada umur 12 MST nilai tertinggi berubah ke perlakuan $\mathrm{PKS}+\mathrm{FA}+\mathrm{ASP}$ dengan peningkatan luas daun $61.75 \%$ dan indeks luas 
daun $61.74 \%$ dibandingkan perlakuan tanpa pemupukan. Nilai terendahnya pada 12 MST terdapat pada perlakuan PKS+FA (tanpa ASP/pengganti pupuk kalium). Hasil tersebut menunjukkan bahwa pupuk $\mathrm{K}$ adalah faktor pembatas dalam menghasilkan luas daun dan indeks luas daun. Sama halnya dengan penelitian Mualim et al. (2009) mengenai tanaman kolesom yang menunjukkan bahwa $\mathrm{K}$ merupakan faktor pembatas yang berperan dalam menghasilkan luas daun dan indeks luas daun yang lebih besar.

Bobot basah dan bobot kering pada awal pengamatan tertinggi terdapat pada perlakuan PKS+ASP, dan dengan berjalannya waktu selama 6 minggu hingga 12 MST berubah ke perlakuan $\mathrm{PKS}+\mathrm{FA}+\mathrm{ASP}$ dengan peningkatan bobot basah $102.04 \%$ dan bobot kering $63.92 \%$ dibandingkan dengan perlakuan tanpa pemupukan. Nilai terendahnya pada 12 MST terdapat pada perlakuan PKS+FA. Menurut Deviona dan Maryani (2009), kalium tinggi akan mengakibatkan daun yang kuat menempel ke batang dan tidak mudah lepas karena fungsi kalium adalah memperkokoh batang dan daun serta buah agar tidak mudah jatuh atau rebah. Pada penelitian ini diduga beberapa daun jatuh dan rebah akibat terkena hujan yang lebat, sehingga perlakuan tanpa ASP (pengganti pupuk K) untuk pengukuran bobot basah dan bobot keringnya menjadi kecil dibanding dengan perlakuan yang lain. Luas daun spesifik (LDS) menunjukkan ketebalan daun. Semakin kecil nilai LDS maka semakin tebal daun tersebut. Semakin besar LDS, maka semakin tipis daun tersebut. Nilai LDS pada awal pengamatan (6 MST), paling besar terdapat pada perlakuan PKS+FA+ASP, namun pada 12 MST berubah ke perlakuan tanpa pemupukan. Hal ini menunjukkan bahwa daun pada perlakuan tanpa pemupukan adalah daun yang paling tipis dibandingkan dengan perlakuan yang lain.

Tabel 2. Pengaruh pemupukan terhadap luas daun, indeks luas daun, bobotbasah, bobot kering dan luas daun spesifik pada siklus 1

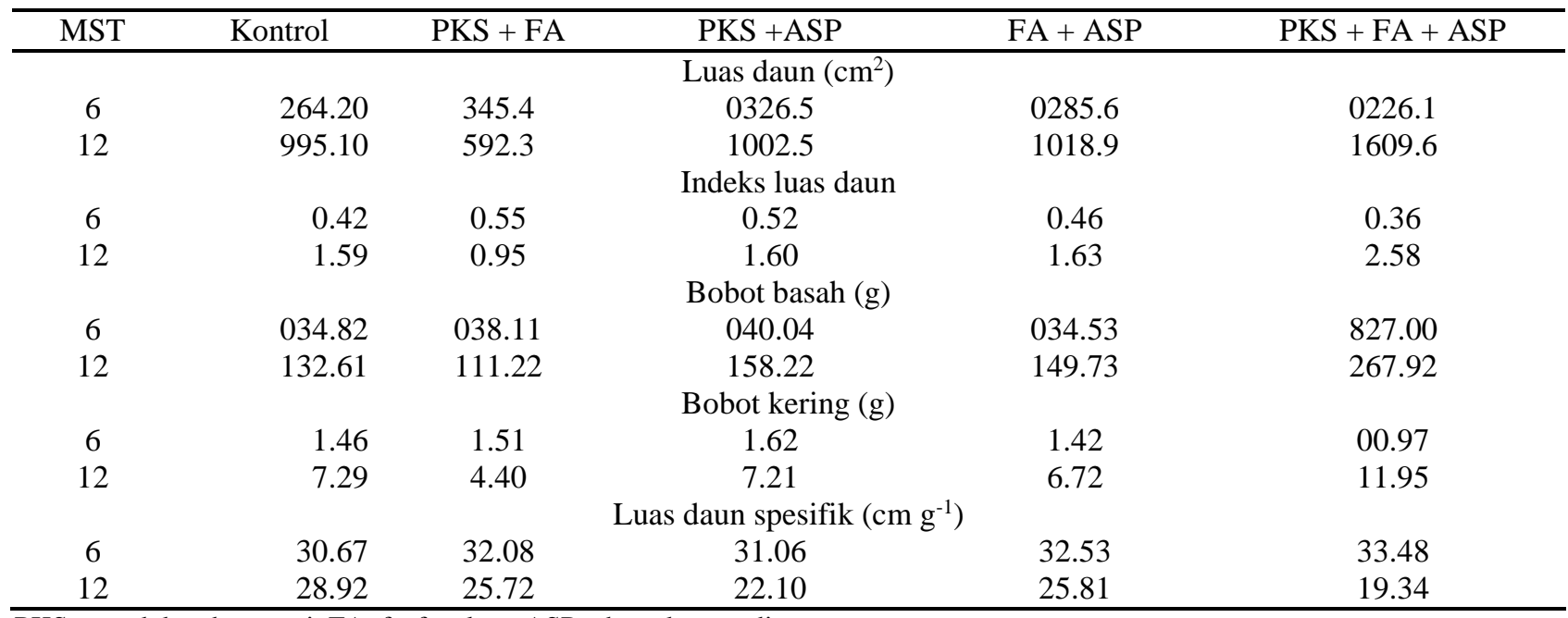

PKS: pupuk kandang sapi, FA: fosfat alam, ASP: abu sekam padi

Laju tumbuh relatif (LTR) dan laju asimilasi bersih (LAB) berfluktuatif setiap pengamatannya (Tabel 3). Laju tumbuh relatif (LTR) menunjukkan peningkatan bobot kering dalam hubungannya dengan bobot awal pada suatu interval waktu. Nilai LTR tertinggi pada minggu ke 6-8 adalah perlakuan PKS+FA+ASP, hasil ini berbeda nyata dengan semua perlakuan.
Nilai LTR selanjutnya tidak berbeda nyata pada semua perlakuan.Nilai awal, tertinggi diperoleh perlakuan PKS+FA+ASP dan nilai di akhir yang tertinggi adalah perlakuan PKS+ASP. Nilai laju tumbuh relatif juga menjelaskan pola pertumbuhan tanaman dari suatu interval waktu yang berhubungan dengan biomassa tanaman. 
Tabel 3. Pengaruh pemupukan terhadap laju asimilasi bersih dan laju tumbuh relatif pada siklus 1

\begin{tabular}{lcccccc}
\hline \multirow{2}{*}{ Perlakuan } & \multicolumn{3}{c}{ Laju tumbuh relatif $\left(\mathrm{g} \mathrm{hari}{ }^{-1}\right)$} & \multicolumn{2}{c}{ Laju asimilasi bersih $\left(\mathrm{g} \mathrm{cm}^{-1}\right)$ hari $^{-1}$} \\
\cline { 2 - 7 } & $6-8$ & $8-10$ & $10-12$ & $6-8$ & $8-10$ & $10-12$ \\
\hline Kontrol & $0.047 \mathrm{~b}$ & $0.030 \mathrm{a}$ & $0.004 \mathrm{a}$ & $0.00029 \mathrm{ab}$ & $0.00027 \mathrm{a}$ & $-0.0001 \mathrm{a}-$ \\
PKS+FA & $0.021 \mathrm{~b}$ & $0.068 \mathrm{a}$ & $-0.021 \mathrm{a}-$ & $0.00009 \mathrm{c} 0$ & $0.00048 \mathrm{a}$ & $-0.0002 \mathrm{a}-$ \\
PKS+ASP & $0.029 \mathrm{~b}$ & $0.016 \mathrm{a}$ & $0.038 \mathrm{a}$ & $0.00014 \mathrm{bc}$ & $0.00010 \mathrm{a}$ & $0.0003 \mathrm{a}$ \\
FA+ASP & $0.029 \mathrm{~b}$ & $0.026 \mathrm{a}$ & $0.030 \mathrm{a}$ & $0.00014 \mathrm{bc}$ & $0.00016 \mathrm{a}$ & $0.0001 \mathrm{a}$ \\
PKS+FA+ASP & $0.086 \mathrm{a}$ & $0.039 \mathrm{a}$ & $0.036 \mathrm{a}$ & $0.00040 \mathrm{a} 0$ & $0.00028 \mathrm{a}$ & $0.0003 \mathrm{a}$ \\
\hline
\end{tabular}

Angka yang diikuti oleh huruf yang berbeda pada kolom yang sama menunjukkan berbeda nyata berdasarkan uji beda nyata jujur (BNJ) 5\%, PKS: pupuk kandang sapi, FA: fosfat alam, ASP: abu sekam padi

Laju asimilasi bersih (LAB) menunjukkan hasil bersih asimilasi per satuan luas daun dan waktu. Nilai LAB pada 6-8 MST tertinggi terdapat pada perlakuan PKS+FA+ASP, berbeda nyata dengan semua perlakuan kecuali perlakuan tanpa pemupukan. Nilai awal tertinggi diperoleh perlakuan PKS+FA+ASP dan nilai di akhir yang tertinggi adalah perlakuan PKS+ASP dan PKS+FA+ASP. Berbeda dengan penelitian Pujisiswanto dan Pangaribuan (2008) yang mengemukakan bahwa nilai LAB seharusnya tinggi di awal karena pada awal pertumbuhan tanaman masih kecil, daun-daun yang terdapat pada tanaman tersebut semua terpapar pada radiasi matahari langsung sehingga kecepatan asimilasi $\mathrm{CO}_{2}$ meningkat yang mengakibatkan nilai LAB tinggi. Ketidaksesuaian ini diduga akibat tanaman torbangun yang tumbuhnya tidak seragam dan lambat.

Semua pengaruh perlakuan berfluktuatif untuk pertumbuhan (LTR) dan produksi daunnya (LAB). Hanya kontrol yang menunjukkan pertumbuhannya semakin menurun setiap waktu dan diiringi produksi daun yang menurun.

\section{Pertumbuhan dengan Panen}

Pengamatan pertumbuhan dengan panen siklus 1 dimulai pada umur 6-12 MST. Pemupukan berpengaruh nyata terhadap tinggi tanaman torbangun mulai minggu ke 7-10 dan berpengaruh sangat nyata pada minggu ke 12 . Hal ini menunjukkan bahwa pemupukan sangat dibutuhkan oleh tanaman torbangun untuk tinggi tanaman.

Tinggi tanaman torbangun beragam pada setiap minggunya (Tabel 4). Tinggi tanaman torbangun mengalami penurunan pada minggu ke9, hal ini disebabkan pada minggu ke-8 adalah waktu panen pucuk pertama untuk tanaman torbangun, sehingga pertambahan tinggi tidak terjadi di minggu ke-9. Tinggi tanaman tertinggi pada 12 MST terdapat pada perlakuan PKS+ASP, meningkat $23.13 \%$ dibandingkan perlakuan tanpa pemupukan. Nilai terendah tinggi tanaman terdapat pada perlakuan tanpa pemupukan.

Tabel 4. Pengaruh pemupukan terhadap rata-rata tinggi tanaman torbangun $(\mathrm{cm})$ pada siklus 1

\begin{tabular}{lcccccccc}
\hline \multirow{2}{*}{ Perlakuan } & \multicolumn{7}{c}{ Umur tanaman (MST) } \\
\cline { 2 - 9 } & 6 & 7 & 8 & $8-9$ & 9 & 10 & 11 & 12 \\
\hline Kontrol & 20.85 & $23.46 \mathrm{~b}$ & $27.62 \mathrm{ab}$ & -0.58 & $27.04 \mathrm{~b}$ & $27.70 \mathrm{~b}$ & 29.77 & $31.51 \mathrm{~b}$ \\
PKS+FA & 19.68 & $22.87 \mathrm{~b}$ & $26.56 \mathrm{~b}$ & -0.50 & $26.06 \mathrm{~b}$ & $26.89 \mathrm{~b}$ & 36.93 & $33.38 \mathrm{~b}$ \\
PKS+ASP & 24.29 & $27.68 \mathrm{a}$ & $32.19 \mathrm{~b}$ & -0.45 & $31.74 \mathrm{a}$ & $32.35 \mathrm{a}$ & 34.83 & $38.80 \mathrm{a}$ \\
FA+ASP & 21.25 & $24.14 \mathrm{ab}$ & $29.28 \mathrm{ab}$ & -0.23 & $29.05 \mathrm{ab}$ & $29.54 \mathrm{ab}$ & 31.99 & $35.06 \mathrm{ab}$ \\
PKS+FA+ASP & 21.32 & $24.83 \mathrm{ab}$ & $28.75 \mathrm{ab}$ & -0.73 & $28.02 \mathrm{ab}$ & $28.13 \mathrm{~b}$ & 30.88 & $33.68 \mathrm{~b}$ \\
Uji F & tn & $*$ & $*$ & & $*$ & $*$ & th & $* *$ \\
\hline
\end{tabular}

Angka yang diikuti dengan huruf yang berbeda pada kolom yang sama menunjukkan berbeda nyata pada uji BNJ taraf 5\%, tn: tidak berbeda nyata pada uji F $5 \%$, *: berbeda nyata pada uji F $5 \%$, **: berbeda sangat nyata pada uji F 5\%, PKS: pupuk kandang sapi, FA: fosfat alam, ASP: abu sekam padi

Lebar tajuk, jumlah cabang, jumlah pucuk dan bobot basah pucuk tidak dipengaruhi oleh pemupukan. Lebar tajuk tertinggi pada 12 MST terdapat pada perlakuan PKS+FA+ASP (Tabel 5), meningkat $13.01 \%$ dibandingkan dengan perlakuan tanpa pemupukan. Jumlah cabang terbanyak pada 6 dan 12 MST adalah perlakuan PKS+FA+ASP, meningkat $41.61 \%$ dibandingkan dengan perlakuan tanpa pemupukan. Jumlah pucuk dan bobot basah pucuk tertinggi pada 6 dan 12 MST adalah perlakuan PKS+FA+ASP, meningkat berturut-turut 38.96 dan $107.44 \%$ 
dibandingkan dengan perlakuan tanpa pemupukan. Terdapat kenaikan bobot pucuk dan jumlah pucuk dari panen 1 ke panen 2 . Hal ini dapat terjadi karena setiap pemetikan pucuk daun, dominasi apikal terganggu sehingga merangsang pertumbuhan lateral.

Tabel 5. Pengaruh pemupukan terhadap lebar tajuk dan jumlah cabang pada 6 dan 12 MST serta jumlah pucuk dan bobot pucuk yang dipanen pada panen ke-1 dan panen ke-2

\begin{tabular}{|c|c|c|c|c|c|}
\hline \multirow[t]{2}{*}{ MST } & \multicolumn{5}{|c|}{ Perlakuan } \\
\hline & Kontrol & PKS + FA & PKS +ASP & $\mathrm{FA}+\mathrm{ASP}$ & $\mathrm{PKS}+\mathrm{FA}+\mathrm{ASP}$ \\
\hline & \multicolumn{5}{|c|}{ Lebar tajuk tanaman $(\mathrm{cm})$} \\
\hline 6 & 21.43 & 21.3 & 21.3 & 23.29 & 21.76 \\
\hline 12 & 33.12 & 35.2 & 34.8 & 36.59 & 37.43 \\
\hline & \multicolumn{5}{|c|}{ Jumlah cabang } \\
\hline 6 & 02.8 & 02.4 & 03.0 & 03.0 & 3.1 \\
\hline 12 & 13.7 & 14.5 & 16.3 & 17.6 & 19.4 \\
\hline Panen ke- & \multicolumn{5}{|c|}{ Jumlah pucuk } \\
\hline 1(8 MST) & 3.17 & 2.47 & 2.77 & 3.47 & 3.67 \\
\hline 2(12 MST) & 6.57 & 7.33 & 7.37 & 8.53 & 9.13 \\
\hline \multicolumn{6}{|c|}{ Bobot pucuk (g) } \\
\hline $1(8 \mathrm{MST})$ & 07.68 & 06.15 & 07.61 & 08.80 & 09.25 \\
\hline 2(12 MST) & 10.75 & 12.91 & 14.59 & 16.70 & 22.30 \\
\hline
\end{tabular}

PKS: pupuk kandang sapi, FA: fosfat alam, ASP: abu sekam padi

Berdasarkan hasil analisis korelasi antara jumlah cabang dan jumlah pucuk berpengaruh sangat nyata $(\mathrm{r}=0.66992, \quad \mathrm{p}<0.001)$. Jumlah cabang yang banyak menunjukkan jumlah pucuk yang banyak. Jumlah cabang berbanding lurus dengan jumlah pucuk. Korelasi antara jumlah pucuk dan bobot pucuk berpengaruh sangat nyata $(\mathrm{r}=0.73618, \mathrm{p}<0.001)$. Jumlah pucuk yang banyak menunjukkan bobot pucuk yang besar.

\section{Siklus 2}

\section{Pertumbuhan Tanpa Panen}

Pengamatan pertumbuhan tanpa panen siklus 2 dimulai umur 17 dan 19 MST. Pemupukan berpengaruh nyata terhadap luas daun, indeks luas daun, bobot basah, dan laju asimilasi bersih. Pemangkasan tidak berpengaruh nyata terhadap bobot kering 17 MST dan luas daun spesifik. Perlakuan tidak dipangkas memberikan hasil yang lebih baik dibandingkan dengan perlakuan dipangkas, hal ini terjadi karena pertumbuhan tanaman torbangun yang lambat, sehingga pertumbuhan lateral pada tanaman dipangkas lebih lambat dibandingkan dominasi apikal pada tanaman yang tidak dipangkas. Interaksi antara pemupukan dan pemangkasan terdapat pada luas daun dan indeks luas daun 19 MST.

Luas daun dan indeks luas daun pada 17 dan 19 MST tertinggi adalah perlakuan PKS+FA+ASP (Tabel 6), meningkat berturutturut 253.40 dan $254.23 \%$ dibandingkan dengan perlakuan tanpa pemupukan. Bobot kering dan bobot basah pada 17 dan 19 MST tertinggi adalah perlakuan PKS+FA+ASP, meningkat 276.92 dan $214.33 \%$ dibandingkan dengan perlakuan tanpa pemupukan. Perlakuan pemupukan PKS+FA+ASP nyata mempengaruhi luas daun, indeks luas daun, bobot basah dan bobot kering. Luas daun spesifik 17 MST tertinggi adalah perlakuan FA+ASP, namun pada 19 MST berubah ke perlakuan PKS+ASP. Data tersebut menunjukkan bahwa daun pada perlakuan PKS+ASP lebih tipis dibandingkan dengan perlakuan yang lain. 
Tabel 6. Pengaruh pemupukan dan pemangkasan terhadap luas daun, indeks luas daun, bobot kering, bobot basah dan luas daun spesifik tanaman torbangun

\begin{tabular}{|c|c|c|c|c|c|c|c|}
\hline \multirow{2}{*}{ MST } & \multicolumn{5}{|c|}{ Pemupukan } & \multicolumn{2}{|c|}{ Pemangkasan } \\
\hline & Kontrol & $\mathrm{PKS}+\mathrm{FA}$ & PKS+ASP & $\mathrm{FA}+\mathrm{ASP}$ & $\mathrm{PKS}+\mathrm{FA}+\mathrm{ASP}$ & Tanpa dipangkas & Dipangkas \\
\hline & \multicolumn{7}{|c|}{ Luas daun $\left(\mathrm{cm}^{2}\right)$} \\
\hline 17 & $403.1 \mathrm{a}$ & $569.8 \mathrm{a}$ & $779.3 \mathrm{a}$ & $765.7 \mathrm{a}$ & $1473.0 \mathrm{a}$ & $1252.3 \mathrm{a}$ & $344.1 b$ \\
\hline \multirow[t]{2}{*}{19} & $889.6 b$ & $845.7 b$ & $928.7 b$ & $753.7 b$ & $3143.9 \mathrm{a}$ & $2151.9 \mathrm{a}$ & $472.8 b$ \\
\hline & \multicolumn{7}{|c|}{ Indeks luas daun } \\
\hline 17 & $0.65 \mathrm{a}$ & $0.91 \mathrm{a}$ & $1.25 \mathrm{a}$ & $1.23 \mathrm{a}$ & $2.36 \mathrm{a}$ & $2.01 \mathrm{a}$ & $0.55 b$ \\
\hline \multirow[t]{2}{*}{19} & $1.42 b$ & $1.35 b$ & $1.49 \mathrm{~b}$ & $1.21 \mathrm{~b}$ & $5.03 \mathrm{a}$ & $3.44 \mathrm{a}$ & $0.76 b$ \\
\hline & \multicolumn{7}{|c|}{ Bobot basah tanaman (g) } \\
\hline 17 & $36.95 \mathrm{a}$ & $37.38 \mathrm{a}$ & $72.83 \mathrm{a}$ & $45.42 \mathrm{a}$ & $114.98 \mathrm{a}$ & $87.34 \mathrm{a}$ & $35.68 \mathrm{~b}$ \\
\hline \multirow[t]{2}{*}{19} & $63.99 b$ & $63.22 b$ & $61.41 b$ & $55.04 \mathrm{~b}$ & 201.14a & $137.80 \mathrm{a}$ & $40.11 b$ \\
\hline & \multicolumn{7}{|c|}{ Bobot kering tanaman $(\mathrm{g})$} \\
\hline 17 & $3.72 \mathrm{a}$ & $3.71 \mathrm{a}$ & $7.56 \mathrm{a}$ & $4.78 \mathrm{a}$ & $11.69 \mathrm{a}$ & $8.84 \mathrm{a}$ & $3.75 \mathrm{a}$ \\
\hline \multirow[t]{2}{*}{19} & $7.80 \mathrm{a}$ & $7.21 \mathrm{a}$ & $6.60 \mathrm{a}$ & $5.84 \mathrm{a}$ & $29.39 \mathrm{a}$ & $18.01 \mathrm{a}$ & $4.73 b$ \\
\hline & \multicolumn{7}{|c|}{ Luas daun spesifik $\left(\mathrm{cm} \mathrm{g}^{-1}\right)$} \\
\hline 17 & $34.84 \mathrm{a}$ & $41.75 \mathrm{a}$ & $41.78 \mathrm{a}$ & $50.25 \mathrm{a}$ & $35.67 \mathrm{a}$ & $39.68 \mathrm{a}$ & $40.15 \mathrm{a}$ \\
\hline 19 & $40.91 \mathrm{a}$ & $38.49 \mathrm{a}$ & $41.25 \mathrm{a}$ & $37.58 \mathrm{a}$ & 40.849 & $42.04 \mathrm{a}$ & $39.49 a$ \\
\hline
\end{tabular}

${ }^{a}$ Angka yang diikuti dengan huruf yang sama pada baris yang sama menunjukkan tidak berbeda nyata pada uji beda nyata jujur (BNJ) taraf 5\%, PKS: pupuk kandang sapi, FA: fosfat alam, ASP: abu sekam padi

Kombinasi perlakuan antara pemupukan dan pemangkasan pada luas daun dan indeks luas daun 19 MST terdapat pada Tabel 7. Nilai tertinggi terdapat pada kombinasi perlakuan PKS+FA+ASP dengan tanpa pemangkasan.Nilai terendahnya terdapat pada kombinasi perlakuan FA+ASP dengan pemangkasan. Hal ini menunjukkan bahwa pupuk pengganti nitrogen (PKS) berpengaruh terhadap jumlah daun tanaman torbangun karena fungsi nitrogen adalah merangsang pertumbuhan vegetatif tanaman (Bennet, 1996). Penelitian ini juga menunjukkan bahwa perlakuan pemangkasan dapat menurunkan biomassa tanaman dan jumlah daun.

Tabel 7. Pengaruh kombinasi perlakuan terhadap luas daun tanaman dan indeks luas daun 19 MST pada siklus 2

\begin{tabular}{|c|c|c|c|}
\hline \multicolumn{2}{|c|}{ Kombinasi perlakuan } & \multirow{2}{*}{ Luas daun $\left(\mathrm{cm}^{2}\right)$} & \multirow{2}{*}{ Indeks luas daun } \\
\hline Pupuk & Pangkas & & \\
\hline \multirow[t]{2}{*}{ Kontrol } & Tanpa & 1399ab & $2.24 \mathrm{ab}$ \\
\hline & Pangkas & $380 \mathrm{~b}$ & $0.61 b$ \\
\hline \multirow[t]{2}{*}{$\mathrm{PKS}+\mathrm{FA}$} & Tanpa & $1321 \mathrm{ab}$ & $2.12 \mathrm{ab}$ \\
\hline & Pangkas & $370 b$ & $0.59 b$ \\
\hline \multirow[t]{2}{*}{ PKS+ASP } & Tanpa & $1368 \mathrm{ab}$ & $2.19 \mathrm{ab}$ \\
\hline & Pangkas & $489 b$ & $0.78 b$ \\
\hline \multirow[t]{2}{*}{$\mathrm{FA}+\mathrm{ASP}$} & Tanpa & $1175 \mathrm{ab}$ & $1.88 \mathrm{ab}$ \\
\hline & Pangkas & $333 b$ & $0.53 b$ \\
\hline \multirow[t]{2}{*}{$\mathrm{PKS}+\mathrm{FA}+\mathrm{ASP}$} & Tanpa & $5496 a$ & $8.79 a$ \\
\hline & Pangkas & $792 b$ & $1.27 \mathrm{~b}$ \\
\hline
\end{tabular}

Angka yang diikuti dengan huruf yang berbeda pada kolom yang sama menunjukkan berbeda nyata pada uji beda nyata jujur (BNJ) taraf 5\%, PKS: pupuk kandang sapi, FA: fosfat alam, ASP: abu sekam padi

Laju tumbuh relatif tidak berbeda nyata dengan semua perlakuan pemupukan (Tabel 8). Laju asimilasi bersih pada perlakuan kontrol berbeda nyata dengan perlakuan PKS+FA+ASP dan kedua perlakuan tersebut tidak berbeda nyata dengan perlakuan yang lain. LTR dan LAB pada perlakuan pemangkasan semua menunjukkan berbeda nyata. LTR dan LAB pada perlakuan kontrol menunjukkan nilai tertinggi.Nilai terendah di semua perlakuan pemupukan terdapat pada perlakuan pemupukan PKS+FA+ASP. Hal ini 
Tabel 8. Pengaruh pemupukan dan pemangkasan terhadap laju tumbuh relatif (LTR) dan laju asimilasi bersih (LAB) siklus 2

\begin{tabular}{lcc}
\hline & Laju tumbuh relatif $\left(\mathrm{g} \mathrm{hari}^{-1}\right)$ & Laju asimilasi bersih $\left(\mathrm{g} \mathrm{cm}^{-1}\right)$ hari $^{-1}$ \\
\hline $0.046 \mathrm{a}$ & $0.00060 \mathrm{a} 0$ \\
& $0.034 \mathrm{a}$ & $0.00033 \mathrm{ab}$ \\
& $0.043 \mathrm{a}$ & $0.00037 \mathrm{ab}$ \\
& $0.032 \mathrm{a}$ & $0.00031 \mathrm{ab}$ \\
PKS+FA+ASP & $0.021 \mathrm{a}$ & $0.00017 \mathrm{~b} 0$ \\
\hline Tidak dipangkas & $0.024 \mathrm{~b}$ & $0.00025 \mathrm{~b} 0$ \\
Dipangkas & $0.046 \mathrm{a}$ & $0.00046 \mathrm{a} 0$ \\
\hline
\end{tabular}

Angka yang diikuti oleh huruf yang berbeda pada kolom yang sama menunjukkan berbeda nyata berdasarkan uji beda nyata jujur (BNJ) 5\%, PKS: pupuk kandang sapi, FA: fosfat alam, ASP: abu sekam padi

\section{Pertumbuhan dengan Panen}

Pengamatan pertumbuhan dengan panen siklus 2 dimulai umur 16 sampai 19 MST. Perlakuan pemupukan berpengaruh nyata terhadap tinggi tanaman (16, 17 dan 19 MST), jumlah cabang (18 dan 19 MST), dan bobot basah pucuk yang dipanen. Perlakuan pemangkasan tidak berpengaruh nyata terhadap jumlah cabang 16 dan 17 MST.Interaksi antara dua perlakuan tersebut hanya terdapat pada peubah tinggi tanaman (semua MST) dan lebar tajuk tanaman pada 19 MST. Tinggi tanaman torbangun tertinggi setiap minggunya terdapat pada perlakuan PKS+FA+ASP (Tabel 9), meningkat $12.77 \%$ dibandingkan dengan perlakuan tanpa pemupukan. Nilai terendah pada umur 16 MST terdapat pada perlakuan PKS+ASP, sedangkan minggu berikutnya nilai terendah terdapat pada perlakuan FA+ASP (tanpa PKS/pengganti pupuk N).Pertambahan tinggi pada tanaman sangat erat hubungannya dengan ketersediaan unsur hara makro yaitu nitrogen $(\mathrm{N})$. Unsur $\mathrm{N}$ berperan dalam merangsang pertumbuhan vegetatif pada tanaman, salah satunya dalam peningkatan tinggi tanaman. Pupuk pengganti N (PKS) sangat berperan dalam pertumbuhan vegetatif tanaman. Tumbuhan membutuhkan $\mathrm{N}$ dalam jumlah yang banyak karena merupakan penyusun utama komponen sel tumbuhan yaitu asam amino dan asam nukleat, selain itu nitrogen banyak terdapat pada klorofil sehingga jika kekurangan nitrogen tanaman akan mengalami klorosis (Bennet 1996). Oleh karena itu defisiensi $\mathrm{N}$ akan cepat menghambat pertumbuhan.

Lebar tajuk tanaman tertinggi setiap minggunya terdapat pada perlakuan PKS+FA+ASP (Tabel 9), meningkat $40.08 \%$ dibandingkan dengan perlakuan tanpa pemupukan. Nilai terendah 16 MST terdapat pada perlakuan PKS+ASP, 17 dan 18 MST pada perlakuan kontrol, dan 19 MST pada perlakuan FA+ASP. Terdapat interaksi antara pemupukan dan pemangkasan pada peubah tinggi tanaman di setiap minggunya dan pada peubah lebar tajuk tanaman hanya terdapat pada 19 MST.

Jumlah cabang tanaman terbanyak terdapat pada perlakuan PKS+FA+ASP (Tabel 9), meningkat $81.06 \%$ dibandingkan dengan perlakuan tanpa pemupukan. Nilai terendahnya pada 16 MST terdapat pada perlakuan kontrol dan pada minggu berikutnya terdapat pada perlakuan PKS+FA. Tidak terdapat interaksi antara pemupukan dan pemangkasan pada peubah jumlah cabang tanaman. 
Tabel 9. Pengaruh pemupukan dan pemangkasan terhadap tinggi, lebar tajuk tanaman dan jumlah cabang tanaman torbangun

\begin{tabular}{|c|c|c|c|c|c|c|c|}
\hline \multirow{2}{*}{ MST } & \multicolumn{5}{|c|}{ Pemupukan } & \multicolumn{2}{|c|}{ Pemangkasan } \\
\hline & Kontrol & $\mathrm{PKS}+\mathrm{FA}$ & PKS+ASP & $\mathrm{FA}+\mathrm{ASP}$ & $\mathrm{PKS}+\mathrm{FA}+\mathrm{ASP}$ & Taıра dipangkas & Dipangkas \\
\hline & \multicolumn{7}{|c|}{ Tinggi tanaman $(\mathrm{cm})$} \\
\hline 16 & $32.23 \mathrm{ab}$ & $33.97 \mathrm{ab}$ & $30.20 \mathrm{~b}$ & $30.63 b$ & $37.02 \mathrm{a}$ & $38.63 \mathrm{a}$ & $26.99 b$ \\
\hline 17 & $33.43 b$ & $36.00 \mathrm{ab}$ & $31.55 b$ & $31.12 b$ & $38.87 \mathrm{a}$ & $40.45 \mathrm{a}$ & $27.93 b$ \\
\hline 18 & $32.62 \mathrm{a}$ & $36.37 \mathrm{a}$ & $30.93 a$ & $30.22 \mathrm{a}$ & $36.60 \mathrm{a}$ & $37.86 \mathrm{a}$ & $28.84 b$ \\
\hline \multirow[t]{2}{*}{19} & $33.82 \mathrm{a}$ & $34.82 \mathrm{a}$ & $30.93 a$ & $29.61 \mathrm{a}$ & $38.14 \mathrm{a}$ & $37.34 \mathrm{a}$ & $29.59 b$ \\
\hline & \multicolumn{7}{|c|}{ Lebar tajuk tanaman } \\
\hline 16 & $30.78 \mathrm{a}$ & $32.92 \mathrm{a}$ & $28.23 \mathrm{a}$ & $31.52 \mathrm{a}$ & $40.53 \mathrm{a}$ & $38.39 \mathrm{a}$ & $27.21 \mathrm{~b}$ \\
\hline 17 & $28.52 \mathrm{a}$ & $34.91 \mathrm{a}$ & $30.67 \mathrm{a}$ & $30.50 \mathrm{a}$ & $43.92 \mathrm{a}$ & $39.98 \mathrm{a}$ & $27.42 b$ \\
\hline 18 & $28.67 \mathrm{a}$ & $33.42 \mathrm{a}$ & $29.92 \mathrm{a}$ & $28.72 \mathrm{a}$ & $40.31 \mathrm{a}$ & $37.68 \mathrm{a}$ & $26.73 b$ \\
\hline \multirow[t]{2}{*}{19} & $29.12 \mathrm{a}$ & $36.63 \mathrm{a}$ & $30.79 \mathrm{a}$ & $27.71 \mathrm{a}$ & $40.79 \mathrm{a}$ & $38.42 \mathrm{a}$ & $27.60 \mathrm{~b}$ \\
\hline & \multicolumn{7}{|c|}{ Jumlah cabang tanaman } \\
\hline 16 & $12.1 \mathrm{a}$ & $13.5 \mathrm{a}$ & $12.7 \mathrm{aa}$ & $13.5 \mathrm{aa}$ & $17.6 \mathrm{a}$ & $14.8 \mathrm{a}$ & $12.9 \mathrm{a}$ \\
\hline 17 & $12.0 \mathrm{a}$ & $11.5 \mathrm{a}$ & $14.4 \mathrm{aa}$ & 11.5aa & $17.8 \mathrm{a}$ & $14.7 \mathrm{a}$ & $12.1 \mathrm{a}$ \\
\hline 18 & $12.7 \mathrm{~b}$ & $11.7 \mathrm{~b}$ & $16.4 \mathrm{ab}$ & $14.3 \mathrm{ab}$ & $22.9 \mathrm{a}$ & $17.6 \mathrm{a}$ & $13.6 \mathrm{~b}$ \\
\hline 19 & $14.1 \mathrm{~b}$ & $12.3 \mathrm{~b}$ & $15.3 \mathrm{ab}$ & $13.9 \mathrm{ba}$ & $25.5 \mathrm{a}$ & $19.3 \mathrm{a}$ & $13.1 \mathrm{~b}$ \\
\hline
\end{tabular}

Angka yang diikuti dengan huruf yang sama pada baris yang sama menunjukkan tidak berbeda nyata pada uji BNJ taraf 5\%, PKS: pupuk kandang sapi, FA: fosfat alam, ASP: abu sekam padi

Interaksi antara pemupukan dan pemangkasan pada peubah tinggi tanaman dan lebar tajuk tanaman tertinggi terdapat pada kombinasi perlakuan PKS+FA+ASP dengan tanpa pemangkasan (Tabel 10). Nilai terendahnya terdapat pada kombinasi perlakuan FA+ASP dengan pemangkasan.Perlakuan pemangkasan mengurangi pertambahan tinggi tanaman dan lebar tajuk tanaman. Hanya pada perlakuan PKS+ASP yang menunjukkan bahwa perlakuan pemangkasan menambah pertambahan lebar tajuk tanaman.

Tabel 10. Pengaruh kombinasi perlakuan terhadap tinggi tanaman dan lebar tajuk tanaman 19 MST pada siklus 2

\begin{tabular}{llcc}
\hline & Kombinasi perlakuan & Tinggi $(\mathrm{cm}) 19 \mathrm{MST}$ & Lebar $(\mathrm{cm}) 19 \mathrm{MST}$ \\
\hline Pupuk & Pangkas & $35.65 \mathrm{ab}$ & $30.07 \mathrm{a}$ \\
Kontrol & Tanpa & $31.99 \mathrm{ab}$ & $28.17 \mathrm{a}$ \\
& Pangkas & $39.73 \mathrm{ab}$ & $46.23 \mathrm{a}$ \\
PKS+FA & Tanpa & $29.90 \mathrm{ab}$ & $27.03 \mathrm{a}$ \\
& Pangkas & $31.48 \mathrm{ab}$ & $30.02 \mathrm{a}$ \\
PKS+ASP & Tanpa & $30.38 \mathrm{ab}$ & $31.57 \mathrm{a}$ \\
& Pangkas & $32.35 \mathrm{ab}$ & $31.48 \mathrm{a}$ \\
FA+ASP & Tanpa & $26.86 \mathrm{~b}$ & $23.93 \mathrm{a}$ \\
& Pangkas & $47.47 \mathrm{a}$ & $54.30 \mathrm{a}$ \\
PKS+FA+ASP & Tanpa & $28.81 \mathrm{~b}$ & $27.28 \mathrm{a}$ \\
\hline
\end{tabular}

Angka yang diikuti dengan huruf yang berbeda pada kolom yang sama menunjukkan berbeda nyata pada uji BNJ taraf 5\%, PKS: pupuk kandang sapi, FA: fosfat alam, ASP: abu sekam padi

Jumlah pucuk dan bobot pucuk tertinggi terdapat pada perlakuan PKS+FA+ASP (Tabel 11). Panen ketiga ini hanya perlakuan tidak dipangkas yang dipanen, karena pada perlakuan dipangkas tanaman torbangun belum mempunyai kriteria layak panen. Bobot basah pucuk total (panen $1+2+3$ ) terdapat pada perlakuan PKS+FA+ASP, meningkat $125.21 \%$ dibandingkan dengan perlakuan tanpa pemupukan. 

Tabel 11. Pengaruh pemupukan terhadap jumlah pucuk dan bobot pucuk yang dipanen pada panen ke-3

\begin{tabular}{|c|c|c|c|c|c|}
\hline \multirow{2}{*}{ Panen ke- } & \multicolumn{5}{|c|}{ Perlakuan } \\
\hline & Kontrol & $\mathrm{PKS}+\mathrm{FA}$ & PKS+ASP & $\mathrm{FA}+\mathrm{ASP}$ & $\mathrm{PKS}+\mathrm{FA}+\mathrm{ASP}$ \\
\hline 3 (17 MST) & $4.8 \mathrm{a}$ & $6.2 \mathrm{a}$ & $\begin{array}{l}\text { Jumlah } \mathrm{p} \\
4 \mathrm{a} \\
\text { Bobot puc }\end{array}$ & $5.3 a$ & $9.2 \mathrm{a}$ \\
\hline 3 (17 MST) & $13.18 \mathrm{a}$ & $27.43 \mathrm{a}$ & $14.55 \mathrm{a}$ & $17.56 \mathrm{a}$ & $39.64 \mathrm{a}$ \\
\hline & \multicolumn{5}{|c|}{ Bobot pucuk total (g) } \\
\hline Panen total & $31.61 \mathrm{a}$ & $46.49 \mathrm{a}$ & $36.75 \mathrm{a}$ & $43.06 \mathrm{a}$ & 71.19a \\
\hline
\end{tabular}

Angka yang diikuti dengan huruf yang sama pada baris yang sama menunjukkan tidak berbeda nyata pada uji BNJ taraf 5\%, PKS: pupuk kandang sapi, FA: fosfat alam, ASP: abu sekam padi

\section{KESIMPULAN}

Hasil penelitian ini menunjukkan bahwa pemupukan lengkap (PKS+FA+ASP) dapat meningkatkan bobot basah pucuk $125.21 \%$ dibandingkan dengan perlakuan tanpa pemupukan. Pemangkasan dapat menurunkan biomasa tanaman dan jumlah daun. Penelitian ini menunjukkan bahwa pertumbuhan tanaman torbangun termasuk lambat, sehingga pemanenan juga harus dilakukan pada umur tanaman yang lebih lama.

Meskipun banyak peubah pengamatan yang menunjukkan tidak berbeda nyata secara statistik, namun berdasarkan nilai tengah pengamatan, perlakuan pupuk PKS+FA+ASP memberikan hasil yang paling tinggi dibanding perlakuan lainnya.

\section{DAFTAR PUSTAKA}

Bennet, W.F. 1996. Plant Nutrient Utilization and Diagnostic Plant Symptoms. Di dalam: Bennet WF, editor. Nutrient Deficiencies \& Toxicities in Crop Plants.Texas Tech University. Amerika (US): The American Phytopathological Society (APS). hlm 2.

Damanik, R. 2005. Effect of Consumption of torbangun soup (Coleus amboinicus Lour) on micronutrient intake of the bataknese lactating women.Media Gizi \& Keluarga. 29(1): 68-73.

Damayanthi, E., Damanik, R., Warsiki, E. 2005. Penundaan kerusakan oleh antioksidan vitamin dan retensinya pada sayur torbangun (Coleus amboinicus Lour.) awet.Prosiding Seminar Perhimpunan Ahli Teknologi Pangan Indonesia (PATPI); 2005 Oktober 14-16; Palembang, Indonesia. Palembang (ID). hlm 1228-1237.
Deviona, Maryani, A.T. 2009. Kajian aplikasi campuran pupuk organik dan pupuk anorganik terhadap pertumbuhan tanaman nilam (pogestemon cablin benth) di bawah naungan. Laporan Penelitian Dosen Muda. Pekanbaru (ID): Lembaga Penelitian Universitas Riau.

Farchany, S.A. 2012. Pemberian kombinasi pupuk organik sebagai pengganti penggunaan pupuk anorganik pada pertumbuhan dan produksi kolesom [skripsi]. Bogor (ID): Institut Pertanian Bogor.

Hardjowigeno, S. 2007. Ilmu Tanah. Jakarta (ID): CV Akademika Pressindo. 284 hal.

Hartmann, H.T., Kester DE. 1983. Plant Propagation-Principles and Practices. New Jersey (US): Prentice Hall International Inc. 238p.

Lingga, P. 1991.Jenis dan kandungan hara pada beberapa kotoran ternak. Bogor (ID): Pusat Pelatihan Pertanian dan Pedesaan Swadaya (P4S) ANTANAN.

Melati, M., Asiah, A., Rianawati D. 2008. Aplikasi pupuk organik dan residunya untuk produksi kedelai panen muda.Bul Agron. 36(3) 204-213.

Mualim, L, Aziz, S.A, Melati M. 2009. Kajian pemupukan NPK dan jarak tanam pada produksi antosianin daun kolesom. $J$ Agron Indonesia. 37(1) : 55 - 61.

Noor A. 2003. Pengaruh fosfat alam dan kombinasi bakteri pelarut fosfat dengan pupuk kandang terhadap $\mathrm{P}$ tersedia dan pertumbuhan kedelai pada ultisol.Bul Agron. 31(3) 100-106.

Pujisiswanto, H., Pangaribuan D. 2008.Pengaruh dosis kompos pupuk kandang sapi terhadap pertumbuhan dan produksi buah tomat.Prosiding Seminar Nasional Sains 
dan Teknologi-II; 2008 November 17-18. Lampung, Indonesia. Lampung (ID): Universitas Lampung. hlm 11-19.

Siagian, M.H., Rahayu M. 2000. Etnobotani Plectranthus amboinicus (Lour.)Spreng di Daerah Batak Toba, Tapanuli UtaraSumatera Utara. Surabaya (ID): Symposium Penelitian Bahan Obat Alami $X$. halaman 163-170.

Soepardie, G. 1983. Sifat dan Ciri Tanah. Bogor (ID): Departemen Ilmu-ilmu Tanah. Institut Pertanian Bogor.164 hal.

Sudaryono. 2002. Sumber K alternatif dan peranan pupuk kandang pada tanaman kedelai di lahan kering Alfisol dan Vertisol. Prosiding Seminar Hasil Penelitian. Bogor (ID): Balai Penelitian dan Pengembangan Tanaman Pangan.

Susanti, H. 2012. Produksi protein dan antosianin pucuk kolesom (Talinum triangulare (Jacq.)Willd) dengan pemupukan nitrogen+kalium dan interval panen [disertasi]. Bogor (ID): Institut Pertanian Bogor.

Sutanto, R. 2002. Penerapan Pertanian Organik: Pemasyarakatan dan Pengembangannya. Yogyakarta (ID): Kanisius. 219 hal. 